Research Article

\title{
Evaluation of gastrointestinal nematode infection and levels of anthelmintic resistance in small-holder goat flocks from three villages around Gaborone, Botswana
}

\author{
Solomon S. Ramabu ${ }^{1,4, *}$, Tove Johansson ${ }^{2}$, Jonas Johansson Wensman ${ }^{3}$ and Johan Höglund ${ }^{2}$ \\ ${ }^{1}$ Botswana University of Agriculture and Natural Resources, Department of Veterinary Sciences. \\ ${ }^{2}$ Swedish University of Agricultural Sciences, Department of Biomedical Sciences and Veterinary Public Health, Section for \\ Parasitology, Uppsala, Sweden. \\ ${ }^{3}$ Swedish University of Agricultural Sciences, Department of Clinical Sciences, Section for Ruminant Medicine, Uppsala, \\ Sweden. \\ ${ }^{4}$ Paul G. Allen School for Global Animal Health, Washington State University, Pullman, WA, United States of America.
}

\section{ARTICLE INFORMATION}

\section{Keywords}

Gastrointestinal nematodes

Goats

Faecal egg count reduction test Anthelmintic resistance

Ivermectin

\section{Article History:}

$\begin{array}{ll}\text { Submission date: } & \text { 14 May } 2019 \\ \text { Revised: } & \text { 12 Dec. } 2019 \\ \text { Accepted: } & \text { 18 Dec. } 2019 \\ \text { Available online: } & \text { 04 Apr. } 2020 \\ \text { https://bojaas.buan.ac.bw }\end{array}$

\section{Corresponding Author:}

Solomon S. Ramabu

$$
\begin{aligned}
& \text { 용 : :(267) } 3350100 \\
& \text { 冝 : (+267) } 3928753 \\
& \text { : ssramabu@buan.ac.bw }
\end{aligned}
$$

\begin{abstract}
This study aimed to investigate: 1) gastrointestinal nematode (GIN) infection in goat flocks, and 2) efficacy of ivermectin treatment in three villages around Gaborone, Botswana. A 100 goats randomly selected from 10 smallholder flocks from Modipane $(n=40)$, Kopong $(n=30)$, and Gakuto $(n=30)$ were evaluated for faecal egg count (FEC), body condition (BCS), FAMACHA ${ }^{\circledR}$ scores (FS), and packed cell volume (PCV) and marked for subsequent identification. Thereafter, all adult goats in participating flocks were treated with ivermectin at 5 $\mathrm{mg} / \mathrm{kg}$ bodyweight. Seventy-four goats that were FEC positive were resampled 11 to 14 days later for a faecal egg count reduction test (FECRT). Mean FEC were in the range $67.5 \pm 14.2$ to $380 \pm 50$ (Mean \pm SEM) eggs per gram (EPG) but varied significantly at $95 \%$ confidence level, between villages and between flocks in the same village. In all but one Modipane flock, the BCS was $>3$ and acceptable. Similarly, only one flock from Kopong had a FS tending to anaemia. All flocks had a mean PCV within the normal range. Notably, the flock with the highest FS had the lowest PCV. Ivermectin was effective except in one flock whose FEC increased post treatment suggesting anthelmintic resistance. In conclusion, GIN infection is common in smallholder goat flocks in Botswana, although there are significant differences in FEC both between villages and between flocks in the same village. Although possible resistance was observed in one flock, the FECRT indicates that ivermectin is still effective in the majority of the flocks.
\end{abstract}

\section{Introduction}

Small ruminants, such as goats, are of major economic importance in developing countries providing meat, milk and skins. These animals are most suitable for rearing by women requiring comparatively less land compared to cattle. Also, in Botswana these animals continue to be reared in periurban areas.

Previous findings have demonstrated that small ruminants in Botswana commonly host gastrointestinal nematodes (GIN) and coccidia which have been estimated to cause between $40-60 \%$ of the mortality in sheep and goat flocks (Segwagwe and
Ramabu, 1999; Moagabo and Baipoledi, 2008). Loss in production associated with heavy worm burden is common (Nsoso et al. 2001; Walker et al. 2015) but is so far unquantified. The impact of GIN can be exacerbated by a low plane of nutrition (Hoste et al. 2005; Torres-Acosta et al. 2012). Under Botswana conditions, goats dependent entirely on pasture in late winter, early spring, and during periods of drought, experience a low plane of nutrition. Anecdotal evidence shows that most smallholder farmers rearing small ruminants in Botswana do not treat their animals against nematode infections. Also, when treatment is performed it is often irregular and potentially inadequate. An inadequate use of de- 
wormers increases the risk of selection for anthelmintic resistance (AR) (Jackson et al. 2012). It is therefore important to determine whether AR to ivermectin that farmers commonly use, is a problem as a first step to working with farmers to address the problem.

The current study was carried out to investigate the presence and impact of GIN infection in goats reared by smallholder farmers in three villages around Gaborone, Botswana. The objective was to use health indicators specifically body condition score (BCS), FAMACHA ${ }^{\circledR}$ score (FS), packed cell volume (PCV), and nematode faecal egg counts (FEC) to compare worm burden between villages and between flocks in the same village. In addition, a faecal egg count reduction test (FECRT) was carried out to determine if ivermectin resistance was present. Variations in the health indicators both between flocks and between villages and the implications thereof are discussed.

\section{Materials and methods}

\section{Study area and goat management}

The study was conducted between September and November 2016. It included ten smallholder goat flocks from three villages around the capital Gaborone. An estimate in the area is 1937 flocks per village. The whole area is semi-arid with dominant acacia bush savannah. Average temperatures are 19 ${ }^{\circ} \mathrm{C}$ in the dry winter months and $33^{\circ} \mathrm{C}$ during the summer. Extreme temperatures with winter frost and up to $40^{\circ} \mathrm{C}$ in the summer are occasionally experienced. The wet season usually occurs between November and April, with 300-500 mm/year average rainfall (Omphile et al. 2004).

All flocks that participated were chosen based on their flock size and the willingness of the farmers to participate. Most flocks consisted of approximately 30 animals. One flock in Kopong had $\approx 100$ animals, whereas two neighbouring farmers in Modipane each had 10-15 animals and they were therefore treated as a single flock. According to the goat owners the deworming of the goats, if it was ever done, was irregular. A farmer in Modipane whose flock was designated flock D reported treating his goats with an anthelmintic. Also, the large Kopong flock referred to above, designated flock $G$, had previously been treated with anthelmintic. None of the flocks had been dewormed in the immediate period before the current study.

All goats were grazed in communal (shared) pastures in the veld in the outskirts of the villages during daytime and housed (kraaled) at night. Access to water was variable. Some goats drank borehole water every day or every second day. Other animals drank from a dam while they were at pasture. Yet others had water access in their kraals. Two of the farmers fed their goats with hay at night. This semiextensive management of goats has previously been described in north-central Botswana by Walker et al. (2015).

\section{Sampling design}

A total of 100 goats from Modipane $(n=40)$, Kopong $(n=30)$ and Gakuto $(n=30)$ villages were randomly selected for the study. Thus, an average of three (3) flocks per village and ten (10) goats per flock. Flocks were designated $\mathrm{A}$ to $\mathrm{J}$ with the following distribution; Modipane (A, B, C, \& D), Kopong (E, F, \& G), and Gakuto (H, I, \& J). The goats were predominantly indigenous Tswana breed. A few nondescript Boer goat crosses were also present. Depending on flock size, every second or third animal caught up to a total of ten animals per flock, was evaluated using body condition score (BSC) (Bath et al. 2005) and FAMACHA ${ }^{\circledR}$ score (Bath and van Wyk, 2009) both of which are 5-point scales. Furthermore, from each animal individual rectal faecal samples were collected in plastic bags and whole blood was collected in vacutainer tubes (Becton Dickinson). Each sampled animal was marked with a spray paint for subsequent identification. Samples were transported the same day in a cooler box to the laboratory for testing and analyses. All goats caught and sampled in each flock were dewormed by subcutaneous administration of 5 mg ivermectin per $\mathrm{kg}$ bodyweight in accordance with the manufacturer's instructions for sheep (Ecomectin $1 \%$, Afrivet). There was no untreated control group because of farmer reluctance to leave some goats in the flock untreated.

\section{Faecal examination}

Faecal egg counts (FEC) were carried out using a modified McMaster method with a diagnostic sensitivity of 50 nematode eggs per gram (EPG) of faeces as previously described (Ramabu, et al. 2015). Briefly, 3 grams of faeces was homogenised in 42 millilitres of water, sieved through a gauze and centrifuged. Water was then replaced with saturated saline where after faecal samples were mixed, and aliquots used to fill a McMaster chamber. Strongyle nematode eggs were counted at $100 \mathrm{X}$ magnification.

After 10-14 days, all FEC positive animals, 74 in number, were retested for FEC with the exception of three animals, one in flock D and two in flock I. A FECRT was performed to determine the efficacy of ivermectin. FECRT was calculated as previously described by Coles, et al. (2006) and resistance was declared when FEC reductions were $\leq 95 \%$ and with a lower $95 \%$ confidence interval of $\leq 90 \%$. If only one of these criteria was fulfilled, resistance was suspected. 
Body condition and FAMACHA ${ }^{\circledR}$ scoring and determination of haematocrit

The subjective measures of body condition (BCS) and FAMACHA $^{\circledR}$ scoring were used to assess the health status of the goats. BCS was rated on a scale of 1 to 5 with 1 being emaciated and 5 being extremely fat (Bath, et al. 2005). Also, the FAMACHA $^{\circledR}$ score was rated on a scale of 1 to 5 with 1 representing red ocular mucous membranes and 5 representing white (pale) mucous membranes (Malan, et al. 2001). Whole blood was collected from the goats and a haematocrit machine (Haematokrit 210, Hettich, Germany) was used to determine packed cell volume.

\section{Results}

\section{Faecal egg counts}

The FEC for goats in the three villages combined ( $\mathrm{n}$ $=100)$ was $184 \pm 22 \mathrm{EPG}($ Mean \pm SEM $)$ and $95 \% \mathrm{CI}$ (139.5-227.5) EPG. Most flocks with FEC in the lower range were in Modipane (Table 1). Notably flock $\mathrm{C}$ in Modipane had significantly higher FEC compared to flocks A, B, and D in the same village. FEC in Gakuto flocks were in the intermediate range (Table 1). FEC in Gakuto at village level [141.67 \pm 26.6 EPG 95\% CI (88.2-195.1)] was similar to that in Modipane [67.5 \pm 14.2 EPG 95\% CI (39.195.9)]. FEC in Kopong [380 \pm 50 EPG 95\% CI (279.4-480.6)] was significantly higher than in Modipane and Gakuto (Table 1). Flocks E and F in Kopong had FEC significantly exceeding other individual flocks in both Modipane and Gakuto villages. Thus, FEC varied significantly between villages and between flocks in the same village.

\section{Faecal egg count reduction test (FECRT)}

All flocks except flock $\mathrm{G}$ in Kopong had a FECR which varied between 63.6 and 100\% (Figure 1). In flock $G$ mean FEC was $250 \pm 79$ EPG before and $316 \pm 82$ EPG after deworming. Consequently, the FECR for this flock was negative (Figure 1), suggesting the presence of ivermectin resistant strongyles in this flock. Also flock I, had a somewhat poorer reduction compared to the majority of the other flocks. In this flock, the reduction was $63.6 \%$ which, according to criteria described by Coles, et al. (1992) warrants suspicion of development of resistance.

\section{Health indicators}

The body condition of the animals ranged from $3.10 \pm 0.09$ to $3.43 \pm 0.14$ which is rated as average (Table 2). Only flock C in Modipane had a BCS < 3 and thus below average body condition. There were no significant differences, at $95 \%$ confidence level, in body condition between goats in the three villages.
The FAMACHA ${ }^{\circledR}$ score ranged from $2.20 \pm 0.13$ to $2.73 \pm 0.14$ which is acceptable (Table 2). Only flock $\mathrm{G}$ in Kopong scored $>3$ tending towards anaemia. There were no significant differences, at $95 \%$ confidence level, in FAMACHA score between goats in the three villages. The PCV ranged from $29.63 \pm 0.75$ to $34.57 \pm 1.03$ which is within the normal range for goats (Jain, 1993). Flock G in Kopong recorded the lowest PCV of 26.3\%. Interestingly, this is the same flock with the highest FAMACHA ${ }^{\circledR}$ score. The PCV of goats in Kopong was significantly less than that in Modipane and Gakuto.

Table 1: A comparison of faecal egg count (FEC) in ten small holder goat flocks from three villages around Gaborone, Botswana. Arithmetic mean and standard error of mean (SEM).

\begin{tabular}{llll}
\hline Area & $\begin{array}{l}\text { Flock } \\
(\mathbf{n}=\mathbf{1 0})\end{array}$ & $\begin{array}{l}\text { Mean } \pm \text { SEM } \\
\text { EPG }\end{array}$ & $\begin{array}{l}\mathbf{9 5 \%} \text { CI } \\
\text { EPG }\end{array}$ \\
\hline $\begin{array}{l}\text { All villages } \\
\text { (n= 100) }\end{array}$ & A-J & $184 \pm 22$ & $140-228$ \\
\hline Modipane & A & $40 \pm 18^{\mathrm{a}}$ & $5-75^{\mathrm{a}}$ \\
& $\mathbf{B}$ & $60 \pm 29^{\mathrm{a}}$ & $3-117^{\mathrm{ab}}$ \\
& $\mathbf{C}$ & $140 \pm 36^{\mathrm{b}}$ & $69-21^{\mathrm{ab}}$ \\
& D & $30 \pm 13^{\mathrm{a}}$ & $5-55^{\mathrm{a}}$ \\
All flocks & A-D & $68 \pm 14^{\mathrm{A}}$ & $39-96^{\mathrm{A}}$ \\
\hline Kopong & $\mathbf{E}$ & $380 \pm 86^{\mathrm{c}}$ & $211-549^{\mathrm{c}}$ \\
& F & $510 \pm 83^{\mathrm{c}}$ & $347-673^{\mathrm{c}}$ \\
& $\mathbf{G}$ & $250 \pm 79^{\mathrm{bc}}$ & $95-405^{\mathrm{bc}}$ \\
All flocks & $\mathbf{E}-\mathbf{G}$ & $380 \pm 50^{\mathrm{B}}$ & $279.4-480.6^{\mathrm{B}}$ \\
\hline Gakuto & H & $225 \pm 60^{\mathrm{b}}$ & $107-345^{\mathrm{bc}}$ \\
& $\mathbf{I}$ & $85 \pm 21^{\mathrm{ab}}$ & $44-126^{\mathrm{ab}}$ \\
& J & $110 \pm 41^{\mathrm{ab}}$ & $30-190^{\mathrm{ab}}$ \\
All flocks & H-J & $142 \pm 27^{\mathrm{A}}$ & $88-195^{\mathrm{A}}$ \\
\hline
\end{tabular}

Flocks are designated A-J. A, B; Means of all flocks in a village. a, b, c, d; Means of individual flocks. Means within a column bearing different letters are significantly different at $95 \%$ confidence level. CI: Confidence interval. EPG: egg per gram

\section{Discussion}

This study was carried out to: 1) investigate gastrointestinal nematodes (GIN) infection in smallholder farmer's goat flocks from three villages around Gaborone, and 2) to determine whether there is anthelmintic resistance (AR) in the area. Furthermore, the goats were assessed for body condition (BCS), as well as their degree of anaemia using packed cell volume (PCV) and FAMACHA® scores. GIN infection is endemic in small ruminant flocks reared under communal grazing conditions in sub-tropical regions (Tsotetsi, et al. 2013; Ramabu, et al. 2015). 
Ramabu et al. (2020). Bots. J. Agric. Appl. Sci. Volume 14 Issue 1: 1-6. ISSN 2661-9008

Table 2: Health indicators of goats from smallholder farmers in three villages around Gaborone, Botswana.

\begin{tabular}{lllllll}
\hline Village & $\begin{array}{l}\text { BCS } \\
\text { Mean } \pm \text { SEM }\end{array}$ & $\mathbf{9 5 \%}$ CI & $\begin{array}{l}\text { FS } \\
\text { Mean } \pm \text { SEM }\end{array}$ & 95\% CI & $\begin{array}{l}\text { PCV } \\
\text { Mean } \pm \text { SEM }\end{array}$ & 95\% CI \\
\hline $\begin{array}{l}\text { All villages } \\
(\mathbf{n}=\mathbf{1 0 0})\end{array}$ & $3.29 \pm 0.06$ & $3.16-3.42$ & $2.39 \pm 0.08$ & $2.23-2.55$ & $32.95 \pm 0.52$ & $31.93-33.97$ \\
\hline Modipane $(\mathbf{n = 4 0})$ & $3.10 \pm 0.09$ & $2.92-3.27$ & $2.20 \pm 0.13$ & $1.93-2.47$ & $34.23 \pm 0.71^{\mathrm{b}}$ & $32.8-35.66^{\mathrm{b}}$ \\
\hline Kopong $(\mathbf{n = 3 0})$ & $3.43 \pm 0.14$ & $3.14-3.72$ & $2.73 \pm 0.14$ & $2.43-3.02$ & $29.63 \pm 0.75^{\mathrm{a}}$ & $28.09-31.17^{\mathrm{a}}$ \\
\hline Gakuto $(\mathbf{n}=\mathbf{3 0})$ & $3.40 \pm 0.10$ & $3.19-3.60$ & $2.30 \pm 0.14$ & $2.02-2.58$ & $34.57 \pm 1.03^{\mathrm{b}}$ & $32.48-36.66^{\mathrm{b}}$ \\
\hline
\end{tabular}

$a, b$ : Means within a column bearing different letters are significantly different at $95 \%$ confidence level. CI: Confidence interval. BCS: Body condition score. FS: FAMACHA® score. PCV: Packed cell volume. SEM: standard error of the mean.

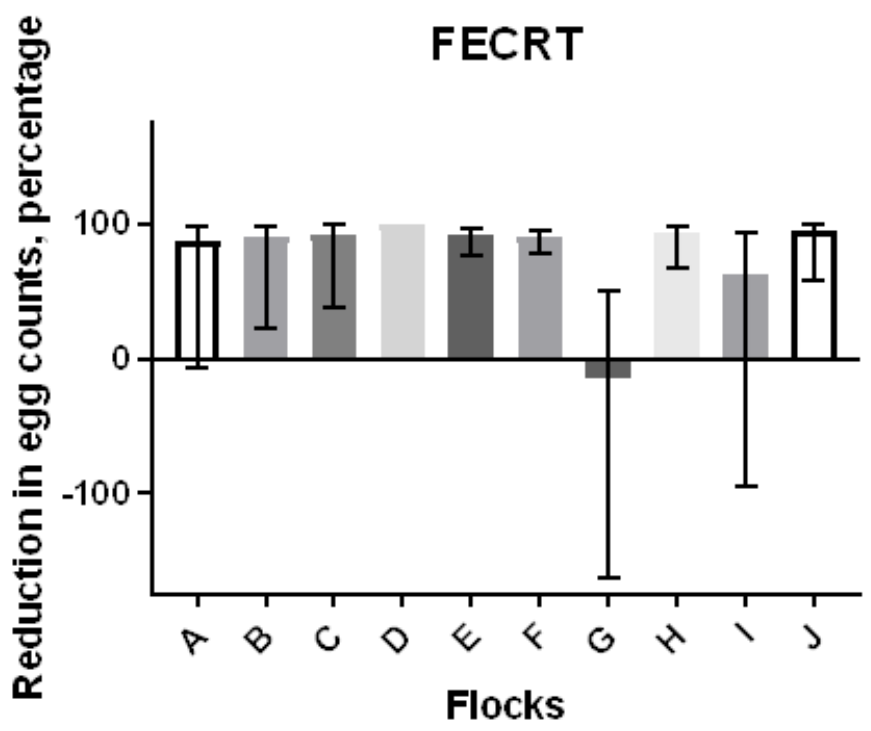

Fig. 1: Results of the faecal egg count reduction test (FECRT) with the error bars representing the confidence interval at $95 \%$. Note that error bars for flock $\mathrm{G}$, which had no reduction in faecal egg counts, are not within the percentage axis. Flock D had a total reduction hence no error bars.

It is well known that high worm burdens contribute to loss of body condition and may make the animals anaemic.

Body conditions of the goats were in general average, a sign of resilience during a dry period when nutritive value in the veld is diminished. In one flock in Modipane, BCS was poor likely attributable to poor husbandry practices. The FAMACHA® score for all flocks but one in Kopong was acceptable. A poor FAMACHA ${ }^{\circledR}$ score indicates heavy infection with Haemonchus contortus (Malan, et al. 2001) requiring anthelmintic treatment. At flock level the findings of the current study suggest that one flock (1/10) required anthelmintic treatment. While PCV was within normal range in all flocks, the flock with the lowest mean PCV of $26.3 \%$ also had the highest FAMACHA® score, consistent with a correlation that was previously reported in sheep (Malan, et al. 2001). The impact of GIN in goat flocks investigated in this study evaluated with BCS, FS, and PCV appears to be low.

Strongyle eggs were present in all of the 10 flocks tested, even though EPG levels varied significantly both between the flocks and between villages. Interestingly, FEC were significantly different between Kopong village on one hand and Modipane and Gakuto villages on the other hand, at 95\% confidence level. The plausible reason for the difference between Modipane (lowest FEC) and Kopong (highest FEC) was that goats in Kopong had access to a green grazing area. It is likely that these goats were more heavily exposed to infective larvae through grazing than those in Modipane that were forced to browse. Thus, the pasture used may determine worm burden in flocks. Nsoso et al. (2001) reported a FEC of $2.03 \pm 0.08\{\log (x+1)\}$ and thus 107 EPG in young goats in March which compared to this study is lower than Kopong and Gakuto but higher than Modipane. This suggests that young 
goats in the wet season tend to have a higher worm burden than adult goats in the dry season.

In addition to variation in worm burden at the village level, the current study revealed significant differences in FEC at a flock level both within and between villages. Flock $\mathrm{C}$ in Modipane had significantly higher FEC compared to Flock D in the same village at $95 \%$ confidence level. The same Flock $\mathrm{C}$ also recorded the poorest body condition score. Incidentally goats in this flock had access to surface water in a dam and the owner used traditional herbal medicine to control worms (personal communication). In contrast Flock D farmer, with the lowest worm burden in the same village reported treating the goats with anthelmintic. Thus, management practices appear to have a significant impact on goat worm burden.

While the FECRT demonstrated that treatment with ivermectin often was effective, Flock $G$ in Kopong was the exception with FEC increasing 10 days post treatment. The most likely explanation is that this drug failure was due to anthelmintic resistance. Flock $\mathrm{G}$ was larger and more commercialized than the rest of the flocks and this farmer also more frequently than others treated his goats for gastrointestinal parasites although it was unclear which anthelmintic was used. Anthelmintic resistance to ivermectin has previously been reported in goats (Jaiswal et al. 2013). However, it is hereby acknowledged that the inclusion criteria for conclusive determination for ivermectin resistance was not fulfilled. Hence the interpretation of flock $\mathrm{G}$ results should be that of possible resistance. Further investigations with a larger sample is required for conclusive findings on anthelmintic resistance.

\section{Conclusions}

We conclude that nematode infection in goat flocks owned by smallholder farmers around Gaborone, Botswana is common. However, significant FEC differences exist between flocks compared at village level and between flocks in the same village. Perhaps owing to resilience of the goats, the impact of the worm burden as determined by BCS, FAMACHA ${ }^{\circledR}$ score, and PCV, was not severe at the village level. Ivermectin is still often effective in treating goats against nematodes. But development of resistance in a goat flock is possible in conditions where the frequency and manner of drug use is uncertain.

\section{Acknowledgments}

This study was supported by the Swedish International Development Cooperation Agency (SIDA) and the Swedish Research Council Grant no. 348-2014-4293. The authors thank Sumbikane Gasebonwe, Jessica Berthelsson, Sara Lysholm,
Moemedi Legodimo and Nico Mosweu for sampling assistance.

\section{Competing interests}

The authors declare that they have no financial or personal relationships that may have inappropriately influenced them in writing this article.

\section{Authors' contributions}

RSS, study design, data acquisition and analysis, and preparation of manuscript; TJ, study design, data acquisition and analysis, and review of manuscript; JJW, study design, data analysis, and review of manuscript; JH, study design, data analysis and interpretation of results, and review of manuscript.

\section{References}

Bath G.F., van Wyk J.A. and Pettey, K.P. (2005) Control measures for some important and unusual goat diseases in southern Africa. Small Ruminant Research 60:127-140.

Bath G.F. and Van Wyk J.A. (2009) The Five Point $\mathrm{Check}^{\odot}$ for targeted selective treatment of internal parasites in small ruminants. Small Ruminant Research 86:6-13.

Coles G.C., Bauer C., Borgsteede F.H.M., Geerts S., Klei T.R., Taylor M.A. and Waller P.J. (1992) World Association for the Advancement of Veterinary Parasitology (W.A.A.V.P.) methods for the detection of anthelmintic resistance in nematodes of veterinary importance. Veterinary Parasitology 44:35-44.

Coles G.C., Jackson F., Pomroy W.E., Prichard R.K., von Samson-Himmelstjerna G., Silvestre A., Taylor M.A. and Vercruysse J. (2006) The detection of anthelmintic resistance in nematodes of veterinary importance. Veterinary Parasitology 136:167-185.

Hoste H., Torres-Acosta J.F., Paolini V., Aguilar-Caballero A., Etter E., Lefrileux Y., Chartier C. and Broqua C. (2005) Interactions between nutrition and gastrointestinal infections with parasitic nematodes in goats. Small Ruminant Research 60:141-151.

Jain N.C. (1993) Essentials of Veterinary Haematology. Philadelphia, USA: Lea \& Febiger.

Jackson F., Varady M. and Bartley D.J. (2012) Managing anthelmintic resistance in goats-Can we learn lessons from sheep? Small ruminant Research 103:3-9.

Jaiswal A.K., Sudan V., Shanker D. and Kumar P. (2013) Emergence of ivermectin resistance in gastrointestinal nematodes of goats in a semiorganized farm of Mathura district-India. Veterinary Arhives 83:275-280.

Malan F., Van Wyk J.A. and Wessels C. (2001) Clinical evaluation of anaemia sheep: early trials. Onderstepoort Journal of Veterinary Research 68:165-174.

Moagabo K.T. and Baipoledi E.K. (2008) Mortalities in goats and sheep in Botswana. Bulletin of Animal Health and Production in Africa 56:259-262.

Nsoso S.J., Machete J.B., Molatole M., Ndebele R.T., Lebani N.N., Chabo R.G., Kalake A.M., Jacyna L., Segadimo B.W. and Mine O.M. (2001) The impact of 
traditional management on seasonal internal parasite burdens and productivity of indigenous Tswana goats in southern Botswana. Onderstepoort Journal of Veterinary Research 68: 101-104.

Omphile U.J., Aganga A.A., Tshireletso K. and Nkele R. (2004) Foraging strategies of sheep and goats under semi-intensive management in Botswana. South African Journal of Animal Science South African Journal of Animal Science 2004, 34 (Supplement 1) (C)South African Society for Animal Science Peerreviewed paper: 8th International Conference on Goats.

Ramabu S.S., Dintsi G., Kobe O., Legwale M.C., Bika I.O., Nthoiwa G.P. and Sebolai B. (2015) Gastrointestinal nematodes of goats reared under communal small scale farming conditions in Botswana. Bulletin of Animal Health and Production in Africa 63:271277.

Segwagwe B.V.E. and Ramabu S.S. (1999) Causes of mortalities in sheep and goats in Botswana. In: A.A.A. Aganga, R.G. Chabo, M. Kgosimore, M. Letso, U.J. Omphile (eds.) Enhancing Sheep and Goat Production in Botswana. Proceedings of the Sheep and Goat Workshop, 19-23 April 1999. Botswana College of Agriculture, Gaborone, Botswana. Pages 224-229.

Torres-Acosta J.F.J., Sandoval-Castro C.A., Hoste H., Aguilar-Caballero A.J., Cámara-Sarmiento R. and Alonso-Díaz M.A. (2012) Nutritional manipulation of sheep and goats for the control of gastrointestinal nematodes under hot humid and sub humid tropical conditions. Small Ruminant Research 103:28-40.

Tsotetsi A.M., Njiro S.T., Katsande C., Moyo G., Baloyi F. and Mpofu J. (2013) Prevalence of gastrointestinal helminths and anthelmintic resistance on small-scale farms in Gauteng Province, South Africa. Tropical Animal Health and Production 45:751-761.

Walker J.G., Ofithile M., Tavolaro F.M., van Wyk J.A., Evans K. and Morgan E.R. (2015) Mixed methods evaluation of targeted selective anthelmintic treatment by resource-poor smallholder goat farmers in Botswana. Veterinary Parasitology 214:80-88. 